\title{
Microbial degradation of total petroleum hydrocarbon in crude oil polluted soil ameliorated with agro-wastes
}

\author{
Agbor R. B. ${ }^{*}$, Antai S. P. ${ }^{2}$ and Nkanang A. J. ${ }^{2}$ \\ ${ }^{1}$ Department of Genetic and Biotechnology, University of Calabar, Calabar, Cross River State-Nigeria. \\ ${ }^{2}$ Department of Microbiology, University of Calabar, Calabar, Cross River State-Nigeria. \\ ${ }^{*}$ Corresponding author. Email: agborreagan@yahoo.com
}

Copyright (@ 2018 Agbor et al. This article remains permanently open access under the terms of the Creative Commons Attribution License 4.0, which permits unrestricted use, distribution, and reproduction in any medium, provided the original work is properly cited.

Received 11 December, 2017; Accepted 22nd January, 2018

\begin{abstract}
Microbial degradation of Total Petroleum Hydrocarbon (TPH) in crude oil polluted soil ameliorated with agrowastes was assessed. Six kilogrammes of each composite soil samples collected from three points were weighed into 150 plastic buckets with drainage holes at the base. The soil samples were spiked with $300 \mathrm{ml}$ of crude oil and treated with agricultural wastes (groundnut husk, maize cobs, cassava peels and empty fruit bunch of oil palm husks) in single and combined form. Experimental data for the total petroleum hydrocarbon content of the soils were collected every 30 days for 90 days. Statistical analysis was done using a three-way analysis of variance (3-Way ANOVA) and significant variations were checked using the least significant difference test at $5 \%$ probability level. The results showed that there were significant variations in the mean values between the different treatment groups. However, the combined amendments $\mathrm{GnH}_{14} \mathrm{P}+\mathrm{Mac}_{14} \mathrm{P}, \mathrm{CasP}_{14} \mathrm{P}+\mathrm{Mac}_{14} \mathrm{P}$ and $\mathrm{GnH}_{14} \mathrm{P}+\mathrm{CasP}_{14} \mathrm{P}$ at $10 \%$ treatment level had the lowest hydrocarbon contents in the soil with mean values of $197.04,202.89$ and 185.34 respectively. While at 90DAST GnH ${ }_{14} \mathrm{P}$ $+\mathrm{Mac}_{14} \mathrm{P}$ and $\mathrm{GnH}_{14} \mathrm{P}+\mathrm{EFBOP}{ }_{14} \mathrm{P}$ had reduced $\mathrm{TPH}$ in soil with mean values of 82.94 and 84.72 respectively. High percentage degradation rates was observed in soil amended with $\mathrm{GnH}_{14} \mathrm{P}, \mathrm{GnH}_{14} \mathrm{P}+\mathrm{CasP}_{14} \mathrm{P}$ and $\mathrm{GnH}_{14} \mathrm{P}+\mathrm{Mac}_{14} \mathrm{P}$ with mean values of $90.85,89.12$ and $88.43 \%$ respectively. It was concluded that the combined treatment with groundnut husks enhances microbial proliferation in soil and produces a strong influence in the reduction of total petroleum hydrocarbons in soils.
\end{abstract}

Key words: Agro-wastes, hydrocarbons, microbial degradation, polluted, soil.

\section{INTRODUCTION}

Biostimulation provides nutrients and suitable physiological conditions for the growth of the indigenous microbial populations, thus increasing metabolic activity, which then degrades the contaminants. This technique has been widely used in reclaiming oil-polluted soil. Obire et al. (2008) investigated the population and types of saprophytic and crude oil-degrading fungal from cow dung and poultry droppings and reported that the addition of cow dung or poultry droppings to polluted soils is beneficial since it enhances the proliferation of mycoflora that may be suppressed by addition of crude oil to the soil. They also reported that inorganic fertilizer enhances microbial utilization of hydrocarbons. The effect of organic nutrient (poultry manure) on biodegradation of crude oil-polluted soil was further assessed with a suggestion that the addition of organic nutrients enhances microbial utilization of crude oil. Hwang et al. (2001) investigated the bioremediation of hydrocarbon-contaminated soil using composting process and found out that mixing of remediated soil with contaminated soil increased the effectiveness of composting. This is because the recycled soils usually have acclimated microorganisms that can significantly affect the degradation rate of contaminants.

Soil structure, which is the form of assembly of soil particles, determines the ability of the soil to transmit air, water, and nutrients to the zone of bioactivity. Vinas et al. (2005) attributed a remarkable shift in the composition of bacterial community to both the biodegradation processes and the addition of nutrient. The addition of nutrient to an ecosystem may result in a selective increase in microorganisms capable of utilizing the hydrocarbons (Venkateswaran et al., 1995; Ferrari et al., 1996). The 
enhancement or reduction will depend upon the chemical composition of the species of microorganisms present within the microbial community of a particular ecosystem (Atlas, 1991). Biological methods have an edge over the physico-chemical treatment regimes in removing spills as they offer in-situ biodegradation of oil fractions by nutrient amendment (Ferrari et al. 1996). Agbim (1985) and Mbagwu (1992) reported on the effectiveness of cassava peels and poultry droppings in enhancing the degradation of crude oil-polluted soil in South-Eastern Nigeria. A greenhouse study aimed at determining the potentials of poultry droppings $(P D)$ and cassava peels $(C P)$ for nutrient enhanced biodegradation of petroleum hydrocarbon (THC) in a well-drained Typic Paleustults using the THC levels and degradation time as remediation indices. They reported that soils treated with NPK fertilizer and CP + PD, the percent THC degradation was $40 \%$ and $41 \%$ for 50 tons NPK and 100 tons NPK fertilizers respectively, and $26 \%$ and $31 \%$ for $25 \mathrm{CP}+25$ tons PD and 50 tons CP + 50 tons PD respectively (Jidere and Akamigbo, 2009). This study exploits the potentials of groundnut husks, cassava peels, maize cobs and empty fruit bunch of oil palm husks in enhancing microbial population of crude oil polluted soil which led to reduction of total petroleum hydrocarbon content in the polluted soils.

\section{MATERIALS AND METHODS}

Total hydrocarbon analysis was carried out in Soil Science Laboratory, University of Calabar, Nigeria. The Nigerian light crude oil was obtained from Nigerian Agip Oil Company (NAOC), located in Port Harcourt, Rivers State, Nigeria. The agro-wastes such as groundnut husks (GH), maize cobs (MC), empty fruit bunch of oil palm (EFBOP) and cassava peels (CP) were collected from local farmers and processing industries in Cross River State, Nigeria.

\section{Production of dispersant from the agricultural wastes}

The collected agro-wastes (GH, MC, EFBOP, CP) were sun-dried for 10 days and blend to powder using electric blender (Model 4250, Braun, Germany). The dispersants were sieved with $2 \mathrm{~mm}$ sieve. Then were labelled and stored in containers.

\section{Soil samples for bioremediation studies}

\section{Site of soil collection}

Sandy-loam soils were obtained from the Experimental site of Faculty of Biological Sciences, University of Calabar, Calabar. The site was used with the intention of using agricultural soil that probably had in the past been under cultivation or grazing and had not been exposed to intentional petroleum hydrocarbon contamination.

\section{Experimental design}

The experiment was conducted using a $3 \times 5 \times 10$ factorial experimental units in a completely randomized design (CRD).

1. Factor 1: The duration (3 levels).

2. Factor 2: The agro-wastes (In single and combined forms).

3. Factor 3: The concentration of the agro-wastes. Pristine control (unpolluted (positive), $0 \%$ ), crude oil control (polluted (negative), $0 \%$ ), 3.33\% and 6.66\% and $10 \%$ of the amendments (5 levels).

\section{Soil sample collection}

Top soils (0 to $25 \mathrm{~cm}$ depth) were evenly obtained from three points, using a Dutch auger, then homogenized to form composite soil sample. Six kilograms of the soil samples was weighed and transferred into each of the hundred and fifty labelled plastic buckets (PB) with drainage holes at the sides and based. The arrangement of the PB was in triplicate using CRD. Artificial pollution was done by introducing $300 \mathrm{ml}$ of crude oil into PB containing the soils, except the pristine soils samples that served as the positive control. The PB containing the polluted soils were mixed thoroughly and allowed to stand for fourteen days (these was to allow indigenous microorganisms to become acclimatized with the new soil condition)

\section{Bio-stimulation study (Application of treatment)}

The polluted soils were treated with the various agrowastes in single and combined form as follows:

1. Groundnut husks 2014 powder $\left(\mathrm{GnH}_{14} \mathrm{P}\right)$ consist of the following treatment groups, pristine soil (+ve control, $0 \% \mathrm{GnH}_{14} \mathrm{P}$ ), crude oil soil (-ve control, $0 \% \mathrm{GnH}_{14} \mathrm{P}$ ), $3 \% \mathrm{GnH}_{14} \mathrm{P}, 7 \% \mathrm{GnH}_{14} \mathrm{P}$ and $10 \% \mathrm{GnH}_{14} \mathrm{P}$.

2. Maize cob 2014 powder $\left(\mathrm{MaC}_{14} \mathrm{P}\right)$ consist of the following groups, pristine soil (+ve control, $0 \%$ $\mathrm{MaC}_{14} \mathrm{P}$ ), crude oil soil (-ve control, $0 \% \mathrm{MaC}_{14} \mathrm{P}$ ), $3 \%$ $\mathrm{MaC}_{14} \mathrm{P}, 7 \% \mathrm{MaC}_{14} \mathrm{P}$ and $10 \% \mathrm{MaC}_{14} \mathrm{P}$.

3. Cassava peels 2014 powder $\left(\operatorname{CasP}_{14} \mathrm{P}\right)$ consist of the following treatment groups, pristine soil (+ve control, $0 \%$ CasP $_{14} \mathrm{P}$ ), crude oil soil (-ve control, $0 \%$ Cas $\mathrm{P}_{14} \mathrm{P}$ ), $3 \% \operatorname{CasP}_{14} \mathrm{P}, 7 \% \mathrm{CasP}_{14} \mathrm{P}$ and $10 \% \mathrm{CasP}_{14} \mathrm{P}$.

4. Empty fruit bunch of oil palm 2014 powder $\left(\mathrm{EFBOP}_{14} \mathrm{P}\right)$ consist of the following treatment groups, pristine soil (+ve control, $0 \%$ EFBOP $_{14} \mathrm{P}$ ), crude oil soil 
(-ve control, $0 \% \quad$ EFBOP $_{14} \mathrm{P}$ ), $3 \%$ EFBOP $_{14} \mathrm{P}, 7 \%$ EFBOP $_{14} \mathrm{P}$ and $10 \%$ EFBOP $_{14} \mathrm{P}$.

5. Groundnut husks 2014 powder $\left(\mathrm{GnH}_{14} \mathrm{P}\right)+$ maize cobs 2014 powder $\left(\mathrm{MaC}_{14} \mathrm{P}\right)$ consist of the following treatment groups, pristine soil (+ve control, $0 \%$ $\mathrm{GnH}_{14} \mathrm{P}+\mathrm{MaC}_{14} \mathrm{P}$ ), crude oil soil (-ve control, 0\% $\left.\mathrm{GnH}_{14} \mathrm{P}+\mathrm{MaC}_{14} \mathrm{P}\right), 3 \% \mathrm{GnH}_{14} \mathrm{P}+\mathrm{MaC}_{14} \mathrm{P}, 7 \%$ $\mathrm{GnH}_{14} \mathrm{P}+\mathrm{MaC}_{14} \mathrm{P}$ and $10 \% \mathrm{GnH}_{14} \mathrm{P}+\mathrm{MaC}_{14} \mathrm{P}$.

6. Groundnut husks 2014 powder $\left(\mathrm{GnH}_{14} \mathrm{P}\right)+$ empty fruit bunch of oil palm 2014 powder $\left(E F B O P{ }_{14} \mathrm{P}\right)$ consist of the following treatment groups, pristine soil (+ve control, $0 \% \mathrm{GnH}_{14} \mathrm{P}+\mathrm{EFBOP}_{14} \mathrm{P}$ ), crude oil soil (-ve control, $\left.0 \% \mathrm{GnH}_{14} \mathrm{P}+\mathrm{EFBOP}_{14} \mathrm{P}\right), 3 \% \mathrm{GnH}_{14} \mathrm{P}+$ EFBOP $_{14} \mathrm{P}, 7 \% \mathrm{GnH}_{14} \mathrm{P}+\mathrm{EFBOP}_{14} \mathrm{P}$ and $10 \%$ $\mathrm{GnH}_{14} \mathrm{P}+\mathrm{EFBOP}{ }_{14} \mathrm{P}$.

7. Groundnut husks 2014 powder $\left(\mathrm{GnH}_{14} \mathrm{P}\right)+$ cassava peels 2014 powder $\left(\mathrm{CasP}_{14} \mathrm{P}\right)$ consist of the following treatment groups, pristine soil (+ve control, $0 \%$ $\mathrm{GnH}_{14} \mathrm{P}+\mathrm{CasP}_{14} \mathrm{P}$ ), crude oil soil (-ve control, $0 \%$ $\left.\mathrm{GnH}_{14} \mathrm{P}+\mathrm{CasP}_{14} \mathrm{P}\right), 3 \% \mathrm{GnH}_{14} \mathrm{P}+\mathrm{CasP}_{14} \mathrm{P}, 7 \%$ $\mathrm{GnH}_{14} \mathrm{P}+\mathrm{CasP}_{14} \mathrm{P}$ and $10 \% \mathrm{GnH}_{14} \mathrm{P}+\mathrm{CasP}_{14} \mathrm{P}$.

8. Maize cob 2014 powder $\left(\mathrm{MaC}_{14} \mathrm{P}\right)+$ empty fruit bunch of oil palm 2014 powder $\left(\mathrm{EFBOP}_{14} \mathrm{P}\right)$ consist of the following treatment groups, pristine soil (+ve control, $0 \% \mathrm{MaC}_{14} \mathrm{P}+\mathrm{EFBOP}_{14} \mathrm{P}$ ), crude oil soil (-ve control, $\left.0 \% \mathrm{MaC}_{14} \mathrm{P}+\mathrm{EFBOP}_{14} \mathrm{P}\right), 3 \% \mathrm{MaC}_{14} \mathrm{P}+\mathrm{EFBOP}_{14} \mathrm{P}$, $7 \% \mathrm{MaC}_{14} \mathrm{P}+\mathrm{EFBOP}_{14} \mathrm{P}$ and $10 \% \mathrm{MaC}_{14} \mathrm{P}+$ $\mathrm{EFBOP}_{14} \mathrm{P}$.

9. Maize cob 2014 powder $\left(\mathrm{MaC}_{14} \mathrm{P}\right)+$ cassava peels 2014 powder $\left(\mathrm{CasP}_{14} \mathrm{P}\right)$ consist of the following treatment groups, pristine soil (+ve control, $0 \%$ $\mathrm{MaC}_{14} \mathrm{P}+\mathrm{CasP}_{14} \mathrm{P}$ ), crude oil soil (-ve control, $0 \%$ $\left.\mathrm{MaC}_{14} \mathrm{P}+\mathrm{CasP}_{14} \mathrm{P}\right), 3 \% \mathrm{MaC}_{14} \mathrm{P}+\mathrm{CasP}_{14} \mathrm{P}, 7 \%$ $\mathrm{MaC}_{14} \mathrm{P}+\mathrm{CasP}_{14} \mathrm{P}$ and $10 \% \mathrm{MaC}_{14} \mathrm{P}+\mathrm{CasP}_{14} \mathrm{P}$.

10. Empty fruit bunch of oil palm 2014 powder $\left(\right.$ EFBOP $\left._{14} \mathrm{P}\right)+$ cassava peels 2014 powder (CasP $\left.{ }_{14} \mathrm{P}\right)$ consist of the following treatment groups, pristine soil (+ve control, 0\% EFBOP ${ }_{14} \mathrm{P}+\mathrm{CasP}_{14} \mathrm{P}$ ), crude oil soil (-ve control, 0\% EFBOP ${ }_{14} \mathrm{P}+\mathrm{CasP}_{14} \mathrm{P}$ ), 3\% EFBOP $_{14} \mathrm{P}+\mathrm{CasP}_{14} \mathrm{P}, 7 \%$ EFBOP $_{14} \mathrm{P}+\mathrm{CasP}_{14} \mathrm{P}$ and $10 \% \mathrm{EFBOP}_{14} \mathrm{P}+\mathrm{CasP}_{14} \mathrm{P}$.

\section{Determination of total petroleum hydrocarbon (TPH)}

The TPH of the soil was determined by air drying $10 \mathrm{~g}$ of collected soil samples from each of the plastic bucket used in the experiment. The dried soil samples were sieved using $1 \mathrm{~mm}$ mesh. A suspension of $10 \mathrm{ml}$-hexane was made and $1 \mathrm{~g}$ of soil was transferred into the suspended solution and shook vigorously using a mechanical shaker. Whatman filter paper was used to filter the solution, the filtrate of which $1 \mathrm{ml}$ of the extract was diluted with $50 \mathrm{ml}$ of n-hexane (Akpoveta et al., 2011).

The absorbance of this solution was read at $430 \mathrm{~nm}$ with Jenway model 6405 UV/Vis Spectrophotometer using nhexane as blank.
1. Percentage hydrocarbon saturation during the 90 study period.

$\left(\mathrm{HC}_{\mathrm{d}} 84 \div \mathrm{HC}_{\text {initial }}\right) \times 100$ (Agbor et al., 2012).

2. Percentage hydrocarbon degradation

$100-\left(\mathrm{HC}_{\mathrm{d}} 84 \div \mathrm{HC}_{\text {initial }}\right) \times 100$ (Agbor et al., 2012).

3. Time required for $100 \% \mathrm{TPH}$ degradation (year) $\left(\mathrm{HC}\right.$ initial $\left.\div \% \mathrm{HC}_{\mathrm{d}} 84\right) \times 100 \div 365$ days (Agbor et al., 2012).

4. Degradation rate of TPH per day

$\left(\mathrm{HC}_{\text {initial }}-\mathrm{HC}_{\mathrm{d}} 84\right) \div \mathrm{T}$ (Agbor et al., 2012).

\section{Statistical analysis}

Data collected were subjected to a three-way analysis of variance (3-way ANOVA) and significant means were separated using least significant difference (LSD) test at $5 \%$ probability level.

\section{RESULTS}

The application of the different agro-wastes in single and combined forms significantly reduces $(P<0.05)$ the total hydrocarbon content of the crude oil-polluted soils. The amended soil with $3 \%$ EFBOP $_{14} \mathrm{P}$ had significantly higher $(\mathrm{P}<0.05) \mathrm{THC}$ in the soil, followed by soils amended with $3 \%$ CasP $_{14} \mathrm{P}+\mathrm{EFBOP}_{14} \mathrm{P}$. These were also followed by soils amended with $\mathrm{GnH}_{14} \mathrm{P}, \mathrm{MaC}_{14} \mathrm{P}, \mathrm{GnH}_{14} \mathrm{P}$ + EFBOP ${ }_{14} \mathrm{P}, \mathrm{MaC}_{14} \mathrm{P}+\mathrm{EFBOP}_{14} \mathrm{P}$ and $\mathrm{GnH}_{14} \mathrm{P}+\mathrm{CasP}_{14} \mathrm{P}$ at $3 \%$ treatment level, which had mean of $580.89 \pm 2.56$ $\mathrm{mg} / \mathrm{kg}, 581.78 \pm 1.24 \mathrm{mg} / \mathrm{kg}, 592.78 \pm 1.10 \mathrm{mg} / \mathrm{kg}, 534.8$ $\pm 1.09 \mathrm{mg} / \mathrm{kg}$ and $547.78 \pm 1.21 \mathrm{mg} / \mathrm{kg}$ respectively, with no significant difference $(P>0.05)$ in mean THC in the soils (Table 1). These were also followed by soils amended with $\mathrm{MaC}_{14} \mathrm{P}, \mathrm{CasP}_{14} \mathrm{P}, \mathrm{EFBOP}_{14} \mathrm{P}, \mathrm{GnH}_{14} \mathrm{P}+\mathrm{EFBOP}_{14} \mathrm{P}$ and $\mathrm{MaC}_{14} \mathrm{P}+\mathrm{EFBOP}_{14} \mathrm{P}$ at $4 \%$ treatment levels, which had no significant differences $(P>0.05)$ in mean THC of the soils. The result also showed that the soil enhanced with $\mathrm{GnH}_{14} \mathrm{P}$ + CasP ${ }_{14} \mathrm{P}, \mathrm{CasP}_{14} \mathrm{P}+\mathrm{MaC}_{14} \mathrm{P}$ and $\mathrm{GnH}_{14} \mathrm{P}+\mathrm{MaC}_{14} \mathrm{P}$ at $10 \%$ treatment level had significantly reduced $(P<0.05)$ THC in the soils with mean values as follows: $185.34 \pm$ $7.34 \mathrm{mg} / \mathrm{kg}, 202.89 \pm 7.22 \mathrm{mg} / \mathrm{kg}$ and $197.04 \pm 7.80 \mathrm{mg} / \mathrm{kg}$ respectively, with no significant differences $(P>0.05)$ in the mean values obtained. These were also followed by soil amended with $\mathrm{GnH}_{14} \mathrm{P}, \mathrm{EFBOP}_{14} \mathrm{P}, \mathrm{GnH}_{14} \mathrm{P}+\mathrm{EFBOP}_{14} \mathrm{P}$ and $\mathrm{MaC}_{14} \mathrm{P}+\mathrm{EFBOP}_{14} \mathrm{P}$ with mean THC of the soils as follows: $245 \pm 9.49 \mathrm{mg} / \mathrm{kg}, 245.89 \pm 1.45 \mathrm{mg} / \mathrm{kg}, 236.21 \pm$ $2.78 \mathrm{mg} / \mathrm{kg}$ and $256.89 \pm 1.24 \mathrm{mg} / \mathrm{kg}$, respectively with no significant differences $(P>0.05)$ in mean values obtained. The results implied that the reduction in the THC of the soil was treatment dose dependent, the higher the treatment levels the lower the THC content in the soils. The results further indicated that the combined forms of the agrowastes were more effective in the degradation of the crude oil in the soils. 
Table 1. Reduction in total hydrocarbon content (TPH) of crude oil-polluted soils amended with agro-wastes.

\begin{tabular}{|c|c|c|c|}
\hline Agro-wastes & $3 \%$ & $6 \%$ & $10 \%$ \\
\hline $\mathrm{GnH}_{14} \mathrm{P}$ & $580.89^{c} \pm 2.56$ & $365.67^{e} \pm 8.97$ & $245.0^{9} \pm 9.49$ \\
\hline $\mathrm{MaC}_{14} \mathrm{P}$ & $581.78^{c} \pm 1.24$ & $428.89^{d} \pm 1.26$ & $298.7^{\mathfrak{f}} \pm 1.28$ \\
\hline $\mathrm{GnH}_{14} \mathrm{P}+\mathrm{MaC}_{14} \mathrm{P}$ & $480.56^{d} \pm 10.98$ & $267.03^{9} \pm 2.20$ & $197.04^{\mathrm{h}} \pm 7.80$ \\
\hline Cas $\mathrm{P}_{14} \mathrm{P}$ & $650.23^{b} \pm 1.20$ & $459.11^{\mathrm{d}} \pm 1.26$ & $308.4^{\dagger} \pm 5.50$ \\
\hline $\mathrm{EFBOP}_{14} \mathrm{P}$ & $723.22^{\mathrm{a}} \pm 1.48$ & $461.44^{\mathrm{d}} \pm 1.35$ & $245.89^{9} \pm 1.45$ \\
\hline $\operatorname{CasP}_{14} \mathrm{P}+\mathrm{EFBOP}{ }_{14} \mathrm{P}$ & $656.0^{\mathrm{b}} \pm 1.59$ & $568.22^{\mathrm{c}} \pm 1.31$ & $376.34^{e} \pm 1.38$ \\
\hline $\mathrm{GnH}_{14} \mathrm{P}+\mathrm{EFBOP}{ }_{14} \mathrm{P}$ & $592.78^{c} \pm 1.10$ & $409.22^{d} \pm 9.87$ & $236.21^{g} \pm 2.78$ \\
\hline $\operatorname{CasP}_{14} \mathrm{P}+\mathrm{MaC}_{14} \mathrm{P}$ & $443.67^{d} \pm 9.93$ & $359.33^{\mathrm{e}} \pm 8.17$ & $202.89^{h} \pm 7.22$ \\
\hline $\mathrm{MaC}_{14} \mathrm{P}+\mathrm{EFBOP}_{14} \mathrm{P}$ & $534.8^{\mathrm{c}} \pm 1.09$ & $424.33^{d} \pm 1.98$ & $256.899 \pm 1.24$ \\
\hline $\mathrm{GnH}_{14 \mathrm{P}}+\mathrm{CasP}_{14} \mathrm{P}$ & $547.78^{\mathrm{c}} \pm 1.21$ & $364.33^{\mathrm{e}} \pm 6.90$ & $185.34^{\mathrm{h}} \pm 7.34$ \\
\hline
\end{tabular}

LSD 21.4.

Mean with the same superscript indicates no significant difference $(P>0.05)$.

Table 2. Effect of the agro-wastes enhancement of microbial degradation of total hydrocarbon content in the soils.

\begin{tabular}{lccc}
\hline Agro-wastes & 30 DAST & 60 DAST & 90 DAST \\
\hline $\mathrm{GnH}_{14} \mathrm{P}$ & $667.80^{\mathrm{b}} \pm 1.98$ & $367.90^{\mathrm{g}} \pm 2.32$ & $155.87^{\mathrm{j}} \pm 2.10$ \\
$\mathrm{MaC}_{14} \mathrm{P}$ & $698.87^{\mathrm{b}} \pm 4.37$ & $423.8^{\mathrm{f}} \pm 2.78$ & $186.71^{\mathrm{j}} \pm 1.87$ \\
$\mathrm{GnH}_{14} \mathrm{P}+\mathrm{MaC}_{14} \mathrm{P}$ & $501.40^{\mathrm{e}} \pm 3.49$ & $360.3^{9} \pm 3.45$ & $82.94^{\mathrm{k}} \pm 1.20$ \\
$\mathrm{CasP}_{14} \mathrm{P}$ & $689.9^{\mathrm{b}} \pm 5.43$ & $494.81^{\mathrm{e}} \pm 4.07$ & $233.03^{\mathrm{i}} \pm 2.89$ \\
$\mathrm{EFBOP}_{14} \mathrm{P}$ & $693.23^{\mathrm{b}} \pm 2.97$ & $489.34^{\mathrm{e}} \pm 4.15$ & $247.98^{\mathrm{i}} \pm 6.09$ \\
$\mathrm{CasP}_{14} \mathrm{P}+\mathrm{EFBOP}_{14} \mathrm{P}$ & $763.28^{\mathrm{a}} \pm 3.98$ & $476.33^{\mathrm{e}} \pm 3.20$ & $360.95^{\mathrm{g}} \pm 5.73$ \\
$\mathrm{GnH}_{14} \mathrm{P}+\mathrm{EFBOP}$ & $432.9^{\mathrm{f}} \pm 3.28$ & $84.72^{\mathrm{k}} \pm 5.78$ \\
$\mathrm{CasP}_{14} \mathrm{P}+\mathrm{MaC}_{14} \mathrm{P}$ & $720.6^{\mathrm{b}} \pm 4.32$ & $316.34^{\mathrm{h}} \pm 4.57$ & $199.96^{\mathrm{j}} \pm 5.87$ \\
$\mathrm{MaC}_{14} \mathrm{P}+\mathrm{EFBOP}_{14} \mathrm{P}$ & $489.6^{\mathrm{e}} \pm 2.97$ & $467.89^{\mathrm{e}} \pm 3.89$ & $163.35^{\mathrm{j}} \pm 3.89$ \\
$\mathrm{GnH}_{14}+\mathrm{CasP}_{14} \mathrm{P}$ & $584.8^{\mathrm{c}} \pm 3.01$ & $368.6^{\mathrm{g}} \pm 3.75$ & $197.46^{\mathrm{j}} \pm 4.02$ \\
\hline
\end{tabular}

LSD 21.4

Mean with the same superscript indicates no significant difference $(P>0.05)$.

DAST, Days After Soil Treatment.

\section{Effect of duration on total hydrocarbon content of the soils}

The results for the effects of duration on the degradation of crude oil polluted soils enhanced with agro-wastes showed that there were significant reductions in the THC content of the soils at 30 days after soil treatment (DAST) application as compared to the crude oil polluted control soils (Table 2). Although, the soil enhanced with $\mathrm{CasP}_{14} \mathrm{P}$ + EFBOP ${ }_{14} \mathrm{P}$ at 30 DAST had the highest THC in the soil. These were followed by soils amended with $\mathrm{GnH}_{14} \mathrm{P}$, CasP ${ }_{14} \mathrm{P}$, EFBOP $14 \mathrm{P}, \mathrm{MaC}_{14} \mathrm{P}$ and $\mathrm{GnH}_{14} \mathrm{P}+\mathrm{EFBOP}_{14} \mathrm{P}$ at 30 DAST with mean $667.80 \pm 1.98 \mathrm{mg} / \mathrm{kg}, 698.87 \pm 4.37$ $\mathrm{mg} / \mathrm{kg}, 689.9 \pm 5.43 \mathrm{mg} / \mathrm{kg}, 693.23 \pm 2.97 \mathrm{mg} / \mathrm{kg}, 720.6 \pm$ $4.32 \mathrm{mg} / \mathrm{kg}$ respectively, with no significant differences $(P>0.05)$ in mean values obtained. The soils amended with $\mathrm{GnH}_{14} \mathrm{P}+\mathrm{MaC}_{14} \mathrm{P}$ and $\mathrm{GnH}_{14} \mathrm{P}+\mathrm{EFBOP}_{14} \mathrm{P}$ at 90 DAST had significantly reduced $(P<0.05)$ THC in the soils, with no significant differences $(P>0.05)$ in the mean values obtained. The reduction in the THC in the soils were also high in soils amended with $\mathrm{MaC}_{14} \mathrm{P}, \mathrm{CasP}_{14} \mathrm{P}+\mathrm{MaC}_{14} \mathrm{P}$ and $\mathrm{MaC}_{14} \mathrm{P}+\mathrm{EFBOP}_{14} \mathrm{P}$ at $90 \mathrm{DAST}$ with no significant differences $(P>0.05)$ in the mean values obtained. That reduction was also next, in soil enhanced with $\mathrm{CasP}_{14} \mathrm{P}$, and EFBOP ${ }_{14} \mathrm{P}$ at $90 \mathrm{DAST}$ with no significant differences $(P>0.05)$ in the mean values obtained. Figure 1 shows that the soil enhanced with the combined form of $\mathrm{GnH}_{14} \mathrm{P}+$ $\mathrm{MaC}_{14} \mathrm{P}$ had high reduction of THC in soil, followed by soils amended with $\mathrm{CasP}_{14} \mathrm{P}+\mathrm{MaC}_{14} \mathrm{P}$, and followed by soils amended with $\mathrm{GnH}_{14} \mathrm{P}+\mathrm{CasP}_{14} \mathrm{P}$. However, soil amended with CasP ${ }_{14} \mathrm{P}+\mathrm{EFBOP}_{14} \mathrm{P}$ had the highest THC in the soil. Table 3 showed that the soil amended with $\mathrm{GnH}_{14} \mathrm{P}$ had the highest percentage hydrocarbon degradation followed by soils amended with $\mathrm{GnH}_{14} \mathrm{P}+\mathrm{CasP}_{14} \mathrm{P}$. This result implies that the ameliorated treatments in single and combined forms were effective in the enhanced microbial degradation. The degradation rate of THC per day decreases with increase duration time. 


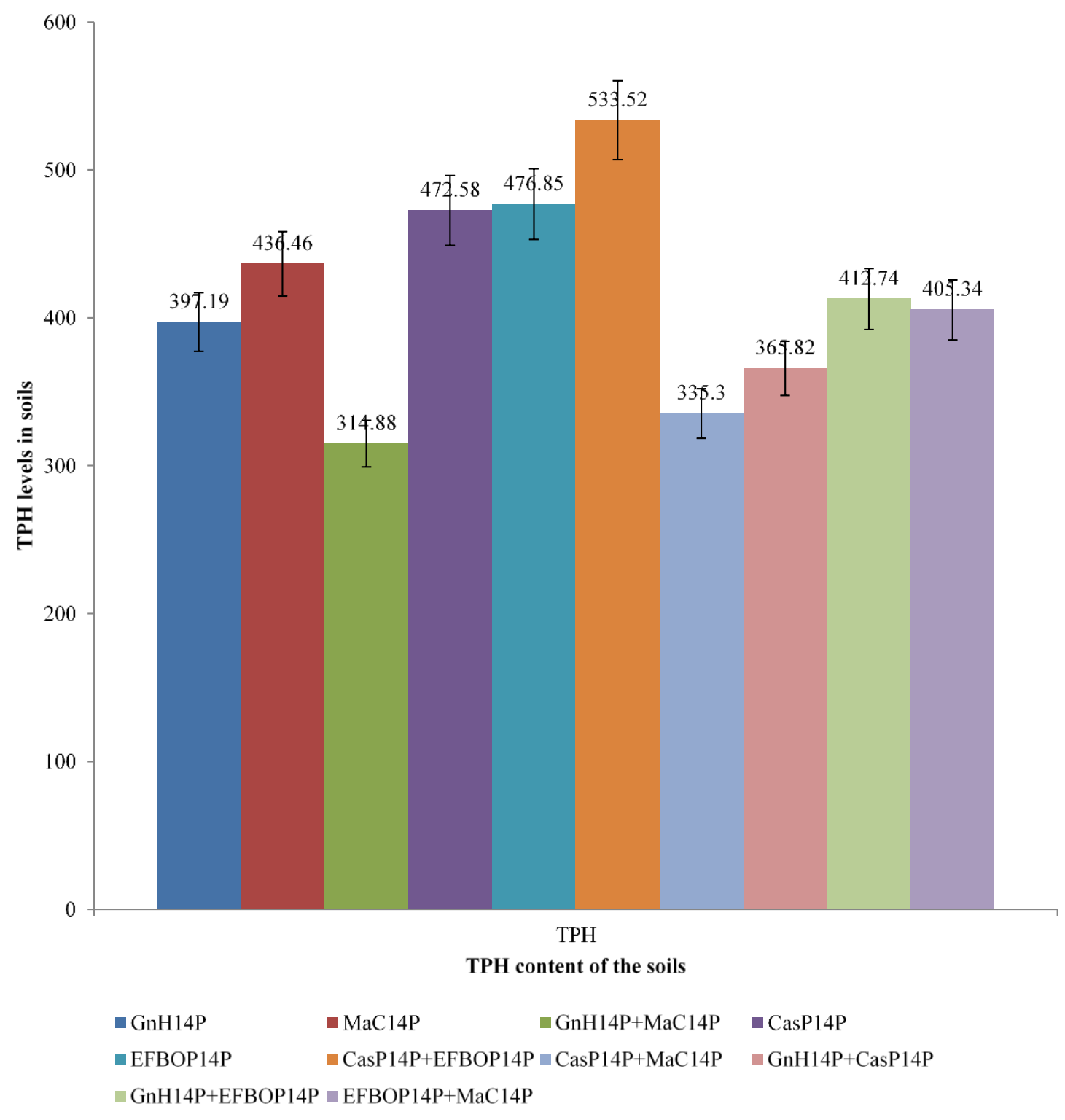

Figure 1. Total petroleum hydrocarbon of the soils amended with different agro-wastes.

\section{DISCUSSION}

The availability of high TPH in soil environment affects the proliferation of soil microorganisms and result in slow degradation of the hydrocarbons in soil. The amendment of the soils with varying levels of crude oil significantly reduced the hydrocarbon content, thus increased the degradation potentials of the hydrocarbons. Ibiene et al. (2011) observed that spent mushroom, cow dung and poultry droppings were effective nutrient sources in the degradation of TPH in the soil. The results obtained from this study showed that the amendments possessed the potentials to stimulate the microbial degradation of petroleum hydrocarbons. This is not in doubt since most of our local farmers used these wastes in increasing the fertility of the soil for improved plant yields. The improved plants yield can thus be attributed to the high nitrogen and phosphorus content of the plant. Stephen et al. (2013) reported a reduction in TPH content of the polluted soil amended with cowpea chaff and observed increase in organic carbon content, nitrogen and moisture content of the soil. The significant reduction in TPH content in the amended soil may be attributed to the high nutrient level especially nitrogen and phosphorus which are essential in stimulating the proliferation of microbial population and activities in soil.

Roger et al. (1993) asserted that the logic of applying fertilizers as bioremediation strategy was that under prespill conditions, crude oil degrading bacteria were limited by the availability of oil as a carbon source. The rate of 
Table 3. Percentage saturation and degradation of total hydrocarbon content in soils.

\begin{tabular}{|c|c|c|c|c|c|c|c|c|c|c|c|c|}
\hline \multirow[t]{2}{*}{ Agro-wastes } & \multicolumn{3}{|c|}{$\%$ saturation } & \multicolumn{3}{|c|}{$\%$ degradation } & \multicolumn{3}{|c|}{$\begin{array}{c}\text { Time required for } 100 \% \mathrm{HC} \\
\text { degradation }\end{array}$} & \multicolumn{3}{|c|}{ Degradation rate of THC per day } \\
\hline & 30DAST & 60DAST & 90DAST & 30DAST & 60DAST & 90DAST & 30DAST & 60DAST & 90DAST & 30DAST & 60DAST & 90DAST \\
\hline $\mathrm{GnH}_{14} \mathrm{P}$ & 39.21 & 21.6 & 9.15 & 60.79 & 78.4 & 90.85 & 0.14 & 0.21 & 0.27 & 34.51 & 22.26 & 17.19 \\
\hline $\mathrm{MaC}_{14} \mathrm{P}$ & 41.03 & 25.18 & 17.5 & 58.97 & 74.82 & 82.5 & 0.14 & 0.22 & 0.30 & 33.48 & 21.32 & 16.85 \\
\hline $\mathrm{GnH}_{14} \mathrm{P}+\mathrm{MaC}_{14} \mathrm{P}$ & 28.22 & 15.68 & 11.57 & 71.78 & 84.32 & 88.43 & 0.11 & 0.19 & 0.28 & 40.06 & 22.38 & 18.00 \\
\hline $\mathrm{CasP}_{14} \mathrm{P}$ & 38.18 & 26.96 & 18.11 & 61.82 & 73.04 & 81.89 & 0.13 & 0.23 & 0.30 & 33.78 & 20.14 & 16.34 \\
\hline $\mathrm{EFBOP}_{14} \mathrm{P}$ & 42.46 & 27.09 & 14.44 & 57.54 & 72.91 & 85.56 & 0.14 & 0.23 & 0.29 & 33.67 & 20.23 & 16.17 \\
\hline $\begin{array}{l}\text { CasP }_{14} \mathrm{P}_{+} \\
\text {EFBOP }_{14} \mathrm{P}\end{array}$ & 38.52 & 33.36 & 22.10 & 61.48 & 66.64 & 77.9 & 0.13 & 0.25 & 0.32 & 31.33 & 20.45 & 14.91 \\
\hline $\begin{array}{l}\mathrm{GnH}_{14} \mathrm{P}_{+} \\
\mathrm{EFBOP}_{14} \mathrm{P}\end{array}$ & 34.80 & 24.03 & 13.87 & 65.2 & 75.97 & 86.13 & 0.13 & 0.22 & 0.29 & 32.75 & 21.17 & 17.98 \\
\hline $\operatorname{CasP}_{14} \mathrm{P}+\mathrm{MaC}_{14} \mathrm{P}$ & 26.05 & 21.10 & 11.91 & 73.95 & 78.9 & 88.09 & 0.11 & 0.21 & 0.28 & 40.48 & 23.11 & 16.70 \\
\hline $\begin{array}{l}\mathrm{MaC}_{14} \mathrm{P}_{+} \\
\text {EFBOP }_{14} \mathrm{P}\end{array}$ & 31.40 & 24.91 & 15.08 & 68.6 & 75.09 & 84.92 & 0.12 & 0.22 & 0.29 & 37.28 & 20.59 & 17.11 \\
\hline 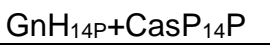 & 32.16 & 21.39 & 10.88 & 67.84 & 78.61 & 89.12 & 0.12 & 0.21 & 0.28 & 39.06 & 22.24 & 16.73 \\
\hline
\end{tabular}

degradation of TPH in the soil per day was higher in the amended soil than the crude oil-polluted control without the amendments. Odu (1981) reported that lack of sources of readily utilizable nitrogen and phosphorus might limit growth of microorganisms and hence crude oil degradation in soil. This implies that the percentage hydrocarbon degradation increases with increase in concentration of amendments. The difference in the rate of degradation among the amendments used may be attributed to the amount of nitrogen and phosphorus each amendment was able to add to the soil to provide the essential nutrients needed for microbial proliferation in the soil. Obasi et al. (2013) noted that the application of the different amendment treatments significantly decreased crude oil toxicity at different degrees by improving the nutrient content and decreasing the total hydrocarbon content of the soil. Akpe et al., (2015) also noted a significant reduction in soil amended with agro-wastes and attributed the reduction in hydrocarbon content in the soil to the level of phosphorus and nitrogen present in the wastes. Sang-Hwan et al. (2007) reported that the initial level of oil-polluted soil was $9320 \mathrm{mg} / \mathrm{kg}$ and reduces by 42 to $51 \%$ in the amended soil, against $18 \%$ reduction in the un-amended soil.

\section{Conclusion}

The potentials of agro-wastes in the enhancement of microbial degradation of total hydrocarbon content in soils was assessed and the finding showed that the agro-wastes in single and combined forms possessed the nutritional components required by the microorganisms to attack and break-down the different hydrocarbon components in the soils. The degradation rate of the THC per day decreases with increased duration time. The use of environmental friendly wastes in polluted sites should encouraged.

\section{CONFLICT OF INTEREST}

The authors declare that they have no conflict of interest.

\section{REFERENCES}

Agbim, N. N. (1985). Potentials of cassava peels as soil amendments: field evaluation. Journal of Environmental Quality, 14, 411-415.

Agbor, R. B., Ekpo I. A., Udofia U. U., Okpako E. C., \& Ekanem B. E. (2012). Potentials of cocoa pod husks and plantain peels in the degradation of total petroleum hydrocarbon content of crude oil polluted soil. Archives of Applied Science Research, 4(3), 1372-1375.

Akpoveta, O. V., Egharevba, F., Medjor, O. W., Osaro, K. I., \& Enyemike, E. D. (2011). Microbial degradation and its kinetics on crude oil polluted soil. Research Journal of Chemical Sciences, 1(16), 8-14.

Akpe, A. R., Esumeh, F. I., Aigere, S. P., Umanu, G. \& 
Obiazi, H. (2015). Efficiency of Plantain Peels and Guinea Corn Shaft for Bioremediation of Crude Oil Polluted Soil. Journal of Microbiology Research, 5(1), 31-40.

Atlas, R. M. (1991). Microbial degradation of petroleum hydrocarbon: An Environmental perspective. Microbiological Review. 45, 180-209.

Ferrari, M. D., Neirotti, E., Albornoz, C., Mostazo, M. R., \& Cozzo, M. (1996). Biotreatment of hydrocarbons from petroleum tank bottom sludge in slurries, Biotechnology Letters. 18, 12411246.

Hwang, E., Namkoog, W., \& Park, J. (2001). Recycling of remediated soil for effective composting of diesel contaminated soil. Compost Science and Utilization, 4(3)143149.

Ibiene, A. A., Orji, F. A., Ezidi, C. O., \& Ngwobia, C. L. (2011). Bioremediation of hydrocarbon contaminated soil in the Niger Delta using spent mushroom compost and other organic waste. Nigerian Journal of Agriculture, Food and Environment, 7(3), 1-7.

Jidere, C. M., \& Akamigbo, F. O. R. (2009). Hydrocarbon degradation in poultry droppings and cassava peels amended typic paleustults in southeastern Nigeria. Journal of Tropical Agriculture, Food, Environment and Extension, 8(1), 24-31.

Mbagwu, J. S. C. (1992). Improving the productivity of a degraded ultisol in Nigeria using organic and inorganic amendments. Part 2: changes in physical properties. Bioresource Technology, 42, 167-175.

Obasi, N. A., Eberechukwu, E., Anyanwu, D. I., \& Okorie, U. C. (2013). Effects of organic manures on the physicochemical properties of crude oil polluted soils, Global Journal of Environmental Biochemistry, 1(1), 66-74.

Obire, O., Anyanwu, E. C., \& Okigbo, R. N. (2008). Saprophytic and crude oil degrading fungi from cow dung and poultry droppings as bioremediating agents. Journal of Agricultural Technology, 4(2), 81-89.
Odu, C. T. I. (1981). Degradation and weathering of crude oil under tropical condition. In: The Petroleum Industry and the Nigerian Environment, Proceeding of an International Seminar. Petroleum Training Institute, Warri, Pp. 143-153.

Roger, C. P., Richard, E. B., Graham, N. G., Copper, E. H., Matthew, J. G., Lute, R. G., David, L. E., Misak-Bernero, V., Senius, J. D., Keim, L. G., Russell, R. C., \& Hinton, S. (1993). The effect of bioremediation on the microbial population of oiled beaches in Prince William Sound, Alaska, 1993 Oil Spill Conference Proceedings. Pp. 469-475.

Sang-Hwan, I., Seokho, I., Dae Yaeon, K., \& Jeong- Gyu, K., (2007). Degradation characteristics of waste lubricants under different nutrient conditions. Journal of Hazardous Material, 143, 65-72.

Stephen, E., Job, O. S., \& Abioye, O. P. (2013). Study On Biodegradation of Diesel Contaminated Soil Amended with Cowpea Chaff. Journal of Science \& Multidisciplinary Research, 2(1), 14-18.

Venkateswaran, K., \& Harayama, S. (1995). Sequential enrichment of microbial populations exhibiting enhanced biodegradation of crude oil. Canadian Journal of Microbiology, 41, 767-778.

Vinas, V., Grifoll, M., Sabate, J., \& Solanas, A. M. (2005). Biodegradation of crude oil by three microbial consortia of different origins and metaboilic capabilities. Journal of Industrial Microbiology and Biotechnology, 28, 252-260. 